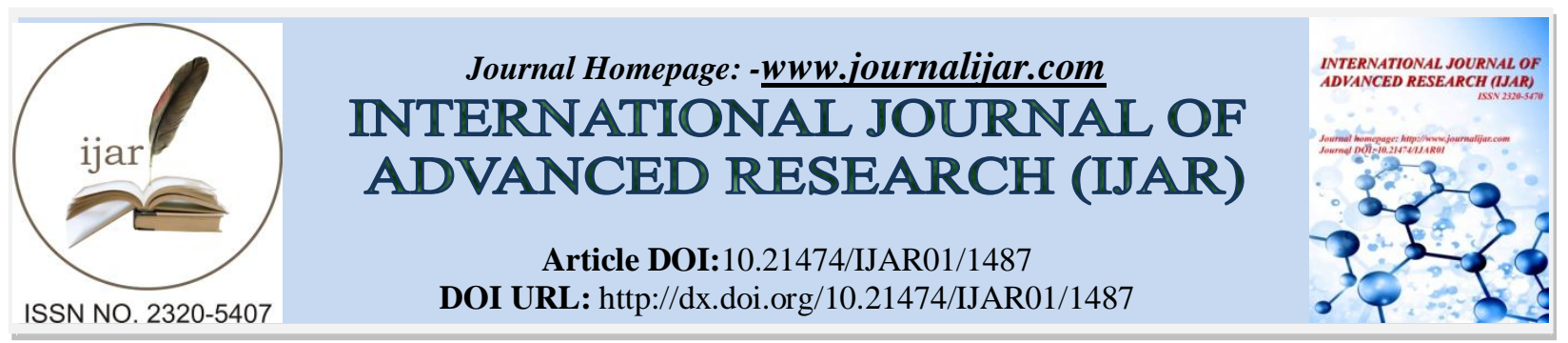

RESEARCH ARTICLE

\title{
PECULIARITIES OF FUNCTIONING OF THE HIGHEST REPRESENTATIVE BODY OF KARAKALPAKSTAN FROM 1932 TO 1937.
}

Imatov Azat Maratovich.

Senior scientific researcher of "Low" Dean at the Karakalpak State University after the name of Berdakh.

\section{Manuscript Info}

Manuscript History

Received: 22 July 2016

Final Accepted: 19 August 2016

Published: September 2016

Key words:-

State authority, Legislative power, executive power, autonomous republic, the Council of People's Commissars, The Congress of Soviets, Executive Committee, presidium, representative office.
Abstract

The article studies the activities,content, and peculiarities of the state agency which carried out the function of the highest Legislative power from the day of foundation of the Karakalpak Autonomous Soviet Socialist Republic in 1932 within the Russian Soviet Federative Socialist Republic to the day of its transfer to the Uzbek Soviet Socialist Republic in 1937.

Copy Right, IJAR, 2016,. All rights reserved.

As is known, in 1924, the Karakalpak Autonomous Region was founded in the Kazakh Autonomous Republic, which was part of the Russian Soviet Federative Socialist Republic.

Although the authorities of the Karakalpak Autonomous Republic were limited, this situation helped to create even better conditions for the economic and cultural development of Karakalpaks. ${ }^{1}$

On June $20^{\text {th }}$, 1930,Karakalpakstan directly became part of Russia, which expedited its transformation from autonomous region to autonomous republic. ${ }^{2}$

The clause defining the legal status of the Karakalpak Autonomous Region within RSFSR was worked out, and approved by the Karakalpak Regional Organization of the All-Russian Communist Party of Bolsheviks before it was submitted for approval to the Karakalpak Regional Soviet. The Presidium of the Executive Committee of the Karakalpak Autonomous Region was tasked with complete editing of this special Clause. ${ }^{3}$ The RSFSR has introduced into its constitution a special paragraph on autonomous republics and autonomous regions. ${ }^{4}$

${ }^{1}$ Koshanov B.A. Karakalpakstan in the second half of the 20's and in 30's//the New History of Uzbekistan. Volume 2. Uzbekistan during the Soviet Colonization.- Tashkent: 200.p.427.

${ }^{2}$ Ibidem.

${ }^{3}$ State Archive of the Republic of Karakalpakstan, f. 6, inventory 12, folder 3, sheet 355.

${ }^{4}$ State Archive of the Republic of Karakalpakstan, f. 229, inventory 1, folder 48, , sheet 28. 
Thus, in less than two years, the Karakalpak Autonomous Region became autonomous soviet socialist republic, achieving a political autonomy and was part of RSFSR until December, 1936. The Karakalpak Autonomous Republic got the opportunity to have its own constitution, the supreme state administrative authority, legislature, government and other attributes of the state.

It is worth noting that at its first stages of development as an autonomous region, the statehood of Karakalpakstan did not have fully developed state legislative institutions, and, therefore, there were many cases of repetition and parallelism in the activities of state institutions. For example, according to the law " The Karakalpak Autonomous Region" adopted on November 1, 1926, if the Congress of Soviets of the Karakalpak Autonomous Republic, directly subject to All-Kazakh Soviet congress, the Central Kazakh Executive Committee and its Presidium, and accountable to them, is held in the period between the congresses of Soviets, the Executive Committee of the region elected by it and its Presidium are acknowledged as the highest state bodies in the territory of the Karakalpak Autonomous Region. ${ }^{5}$

In general, when we studied the activities of the state authority and other administrative bodies of the period during which the Karakalpak Autonomous Region was organized, we found out that the responsibilities of different state bodies were not clearly delimited, and there were neither the main features of the Legislative power nor the representative capacity in their activities. It was clear that each of them executed the administrative functions inconsistent with their authorities whereas the state authority and administrative bodies tried to execute the duties of Legislative power at the same time.

It also should be pointed out that the Soviet administration and the Communist Party carried some weight in the establishment of the state institutions of the Karakalpak Autonomous Region and in their activities, in the formation of the forms of state laws and state institutions, and in the development of the living standard of Karakalpaks and their society though somewhat negatively.

These facts, proper to state authority and government agencies during the formation of the Karakalpak Autonomous Republic, and even during its further development may be stated to have been noticed at the next stage of development when the Karakalpak statehood became the Karakalpak Autonomous Soviet Socialist Republic.

However, when the Karakalpak statehood developed as the Autonomous Soviet Socialist Republic, the state legal institutions developed to some extent, and there even was revival in their law-making activity.

There were attempts to limit clearly, within the law, the responsibilities of different branches of the state bodies, and the state administrative institutions, which were to play the role of legislative bodies.

The Soviet of People's Commissariat, which was to hold a certain executive power in the upper governing bodies, was set up and its responsibilities were defined.

Furthermore, the Constitution of the Republic of Karakalpakstan declared that the power within the KKASSR belongs to the Soviets of workers, peasants and Red Guards ${ }^{6}$.

The Soviets of the deputies of workers, peasants and Red Guards in Karakalpak ASSR were mainly to carry out the responsibilities of Legislative power.

The first founding congress of the deputies of workers, peasants and Red Guards of Karakalpak ASSR started its work in the city of Turtkul on May 25, in $1932^{7}$.

It is worth mentioning that this congress had a great importance for Karakalpak people. The congress elected the Central Executive Committee of Karakalpak ASSR, the Soviet of People's Commissars which served as legislative, executive and administrative bodies and their heads.

\footnotetext{
${ }^{5}$ Akhudjanov L.M. Creation and Development of the Socialist Statehood in Soviet Karakalpakiya. - Nukus, 1984. p.65.

${ }^{6}$ Erniyazova G. The Constitutional Bases of Development of Karakalpakstan. N.: Bilim, 1992. p.35.

${ }^{7}$ Erniyazova G. The Constitutional Bases of Development of Karakalpakstan. N.: Bilim, 1992. p.24.
} 
In addition, the first congress of deputies of workers, peasants and red guards of Karakalpak ASSR adopted the law "On the State System of Karakalpak ASSR" "which had a great historical importance.

Furthermore, it is worthwhile noting that between the congresses of deputies of workers, peasants and red guards of Karakalpak ASSR, the Central Executive Committee of the Karakalpak ASSR adopted a number of legislative documents having the power of law.

For example, in 1932, the Central Executive Committee of KKASSR adopted decrees "On The Council of People's Commissars of KKASSR," "On the Presidium and Members of the Central Executive Committee of KKASSR"10, and in the month of October, the decrees "On the Regulations of the Sessions of the Council of People's Commissars of KKASSR" 11 , "On the Consultants of the Central Executive Committee and the Council of People's Commissars of KKASSR" ${ }^{\prime 2}$ were adopted. These decrees were the documents of great value in the state building in Karakalpak ASSR.

These data indicate that, although the functions of the Legislative power were the responsibility of the Soviet (Council) of the deputies of workers, peasants and red guards of Karakalpak ASSR, at the same time, the Central Executive Committee of the Karakalpak ASSR also tried to carry out this duty.

Here the drawing up and adoption of the Constitution of the Karakalpak ASSR, which for the first time had delineated the authorities of the state authority and the governing bodies, their principles of activity and legal status, were of great importance in state building in the Karakalpak ASSR.

On March 7, 1933, the second session of the Central Executive Committee of the Karakalpak ASSR, looked through the draft of the Constitution and adopted it, issuing an order on its fulfillment. ${ }^{13}$ On December 21, 1934, the second Congress of the Soviets of the Karakalpak ASSR was opened. The Congress issued a decree on complete affirmation of the Constitution of the Karakalpak ASSR. ${ }^{14}$

In general, the Constitution of 1934 consisted of 6 divisions, 17 chapters and 110 clauses. ${ }^{15}$ This constitution of the KKASSR had delineated for the first time the authorities of the state authority and governing bodies of the KKASSR, their principles of activity and legal status.

For instance, the Constitution of KKASSR declared that authority within its territory belongs to the Soviets of deputies of workers, peasants and red guards, and according to the Constitution All-Karakalpak Congress of Soviets was acknowledged as the supreme authority in the territory of Karakalpakstan, and between the congresses the Central Executive Committee carried out that function. ${ }^{16}$

According to the clause 37 of the Fundamental Law, the Congress of the Soviets is considered to be the supreme administrative body in the territory of the KKASSR. The congresses were convened by the Central Executive Committee in accordance to the terms of the USSR and the RSFSR Soviets' congresses. In the territory of the Karakalpak ASSR, the Congress of Soviets consisted of the delegates elected by District and City Soviets, each delegate representing 2000 people, and 400 electors in plants and fabrics. ${ }^{17}$

\footnotetext{
${ }^{8}$ State Archive of the Republic of Karakalpakstan, f. 229, inventory 1, folder 67

${ }^{9}$ Idem.

${ }^{10}$ State Archive of the Republic of Karakalpakstan, f. 229, inventory 1, folder 66.

${ }^{11}$ State Archive of the Republic of Karakalpakstan, f. 229, inventory 1, folder 65.

${ }^{12}$ State Archive of the Republic of Karakalpakstan, f. 229, inventory 1, folder 64.

${ }^{13}$ Erniyazova G. The Constitutional Bases of Development of Karakalpakstan. N.: Bilim, 1992. p.32.

${ }^{14}$ Erniyazova G. The Constitutional Bases of Development of Karakalpakstan. N.: Bilim, 1992. p.33.; Congresses of Soviets of Union and Autonomous Soviet Socialist Republics of Central Asia.V. 7. -M.: Gosyurizdat, 1965. pp.439-461.

${ }^{15}$ Erniyazova G. The Constitutional Bases of Development of Karakalpakstan. N.: Bilim, 1992. p.34.; State Archive of the Republic of Karakalpakstan, f. 229, inventory 1, folder 51, sheet 38.

${ }^{16}$ The Constitution of 1932 of Karakalpak ASSR, clauses 3 and 4. The Republic of Karakalpakstan, The Central State Archive, f. 229, inventory

1, folder 51, sheet 1.: Erniyazova G. The Constitutional Bases of Development of Karakalpakstan. N.: Bilim, 1992. p.35/

${ }^{17}$ Erniyazova G. The Constitutional Bases of Development of Karakalpakstan. N.: Bilim, 1992. p.38.
} 
Of course, this rule was thought to be the most optimal for the Karakalpak ASSR. In other republics, another rule was laid down. For instance, in Mordovia one deputy was elected out of 12000 people, whereas in Yakut ASSR one deputy was elected out of 5000 people. $^{18}$

The authorities of the Congress of the Soviets of Karakalpak ASSR was defined in clause 41 of the Constitution. In accordance with it, the following powers were given to the Congress of the Soviets of the Karakalpak ASSR: the adoption of the Fundamental Law, its complementation and application, along with it affirmation of certain amendments introduced into the Constitution by the Central Executive Committee between the Congresses of the autonomous republic Soviets; Election of deputies to the Central Executive Committee, to All-Union and AllRussian congresses of Soviets; general administration of policy, national economy, culture, state building; approval of the budget, setting local taxes according to the laws of the USSR and RSFSR; adoption of the plans of the national economy and the budget in the territory of the autonomous republic in accordance with the laws of the USSR and RSFSR; adoption of the regulations on the people's commissars'. ${ }^{19}$

The Central Executive Committee, which was the supreme body of the state authority in the Karakalpak ASSR, was elected in the period between the congresses of the Soviets of Karakalpak ASSR.

The powers of the congress of the Soviets and the Central Executive Committee of the Soviets of the Karakalpak ASSR included all issues of state importance which were within the range of powers of Karakalpak ASSR.

In addition, the powers of the Central Executive Committee of the autonomous republic were defined (clauses 42$50)$.

According to the abovementioned clauses, the Central Executive Committee of Karakalpak ASSR was the supreme governing body having complete power over the legislative, administrative and supervisory bodies. The central Executive Committee of the Republic approved decrees and orders on its own initiative, at the same time exemined and adopted the draft laws put forward by the Council of People's Commissars' of Karakalpak ASSR.

In the periods between the sessions of the Central Executive Committee, the Presidium of the Central Executive Committee performed the duties of the legislative, executive, administrative and supervising bodies, and acted in accordance with the special Regulation adopted by the Central Executive Committee of the Soviets of Karakalpak ASSR. The Presidium supervised the observance of the constitutions of the USSR, RSFSR, and the KKASSR, and the fulfillment of the decrees of the congresses of the Soviets and its Central Executive Committee by all administrative bodies. It adopted necessary decrees, orders and edicts on behalf of the Central Executive Committee during the recess between its sessions.

To control the activities of the state authority and controlling bodies, departments, committees and commissions were set up at the Presidium of the Karakalpak ASSR Central Executive Committee of Soviets. The Presidium of the Central Executive Committee brought up for discussion important politico-economical, socio-cultural problems of Karakalpakstan and passed resolutions.

The Constitution of Karakalpak ASSR of 1934 affirmed the powers of the Soviet of People's Commissars, thus, a state institution that was to carry out to some degree the functions of the executive power in the system of the highest governing bodies, was established. That is, in accordance with the clause 56 of the Constitution of 1934, it was considered as both an executive and administrative body. The Republican Soviet of People's deputies got the right to administer all branches generally and some branches immediately. It issued decrees and orders within the frame of rights granted by the Central Executive Committee of the Karakalpak ASSR and according to the Regulation on itself. The Soviet of People's Deputies was organized by the Central Executive Committee in accordance with the Fundamental Law (Constitution).

The Soviets of People's Commissars of KKASSR examined the drafts of some documents and orders proposed by some institutions and approved them. It had the right to suspend and abolish the decrees of the Soviet of People's Commissars of the autonomous republic.

\footnotetext{
${ }^{18} \mathrm{Idem}$.

${ }^{19}$ Nietullaev S.D. The Constitutional Right of the Republic of Karakalpakstan.- N.: Karakalpakstan, 2005.p.22.
} 
It should be particularly noted that the clause 19 of the Fundamental Law ran that all the decrees, orders and edicts of the Central Executive Committee, of its Presidium, of the Soviet of the USSR People's Commissars, of AllRussian Executive Committee, of its Presidium, and of the Soviet of the RSFSR People's Commissars on all people's Commissars' united systems were to be directly observed in the territory of Karakalpak ASSR.

However, it should be particularly noted as an acceptable achievement from today's point of view that if the Central Executive Committee of KKASSR and its Presidium found it difficult to fulfill the decrees and orders of all superior central institutions, they had the right to approach All-Russian Central Executive Committee and the USSR Central Executive Committee with a proposal to abolish or change them. If the Central Executive Committee of Karakalpak ASSR and its Presidium were dissatisfied with the directives and orders of the RSFSR Soviet of People's Commissars, they had the right to inform of it the RSFSR central Executive Committee. ${ }^{20}$

The Constitution defined the status of the Karakalpak National Statehood. Therefore, the Constitution of Karakalpak ASSR of 1934 can be said as a significant achievement of Karakalpak Statehood and society. On the other hand, the Constitution of 1934 was brought in line with the authoritarian system which dominated then, and the principle of separation of powers had not been fully developed in it yet.

In general, the state legal institutions were developed to some extent at the stage when the statehood of Karakalpakstan developed as an autonomous republic. There were attempts to delineate various branches of administrative bodies. The branch of administration, whose duty to a certain degree was to carry out the duties of the executive power in the system of superior administrative bodies, was established.

Thus, the study of the relevant literature and documents allow us to say that during thefoundation of the Karakalpak ASSR, and its further development the following peculiarities were found in the activities of the state authority and the administrative bodies:

* there were attempts tolegally draw line between different branches of power;

* the establishment of the branch of administration, which was obliged by law to carry out the duties of the executive power within the system of superior administrative bodies;

* several government institutions tried to do the duties of the Legislative power;

* the government agencies, which were obliged to do the duties of the Legislative power, did not have the principal attributes of the Legislative power as well as the duties representative body.

\footnotetext{
${ }^{20}$ idem.P. 21.
} 